\title{
FATHOM
}

FATHOM

a French e-journal of Thomas Hardy studies

$1 \mid 2013$

The Letter

\section{Women of Letters and the Irony of Life}

"An Imaginative Woman" and "On the Western Circuit"

"An Imaginative Woman » et " On the Western Circuit ": femmes de lettres et ironies de la vie

\section{Stéphanie Bernard}

\section{OpenEdition}

\section{Journals}

\section{Electronic version}

URL: http://journals.openedition.org/fathom/137

DOI: $10.4000 /$ fathom.137

ISSN: 2270-6798

Publisher

Association française sur les études sur Thomas Hardy

\section{Electronic reference}

Stéphanie Bernard, « Women of Letters and the Irony of Life », FATHOM [Online], 1 | 2013, Online since

17 May 2013, connection on 01 May 2019. URL : http://journals.openedition.org/fathom/137 ; DOI

10.4000/fathom.137

This text was automatically generated on 1 May 2019. 


\title{
Women of Letters and the Irony of Life
}

\author{
"An Imaginative Woman" and "On the Western Circuit" \\ "An Imaginative Woman » et " On the Western Circuit » : femmes de lettres et \\ ironies de la vie
}

Stéphanie Bernard

1 To introduce the first text that will be discussed in this paper, I will quote Thomas Hardy's preface to the 1894 Wessex Edition of the collection entitled Life's Little Ironies:

On the following collection the first story, "An Imaginative Woman", which has hitherto stood in Wessex Tales, has been brought into this volume as being more nearly its place, turning as it does upon a trick of Nature, so to speak, a physical possibility that may attach to a wife of vivid imaginings, as is well known to medical practitioners and other observers of such manifestations (Hardy 1967, 31).

The opening lines let the reader expect some slightly sarcastic tale dealing with an idealistic young woman named Ella Marchmill, who comes to be disillusioned about her marriage to William Marchmill, and tries to escape dull reality through the power of imagination. But the little ironies in her life turn out to be tragic as the story ends up with notions of death, bereavement and scorn.

3 For something more - something ungraspable - takes place behind the scene of the young woman's daydreaming. A disembodied tale of desire and words shines through the fabric of the narrative text as this "Imaginative Woman" falls in love with a man of letters she never meets. What is it that lies behind the soft veil of Hardy's fable? What makes the even surface of the story and of its mellifluous title reveal the depths of human despair, desire and irremediable loss?

4 Ella is a dreamer, not only by nature but also as a way to escape the dissatisfaction she feels with her existence. For her feminine condition makes her dependent on her husband's money and status, both derived from his business as a gun-maker. The beautiful, elegant and inspired woman is married to a self-satisfied, down-to-earth business man and has to make do with it: "She came to some vague conclusions, and since 
then had kept her heart alive by pitying her proprietor's obtuseness and want of refinement, pitying herself, and letting off her delicate and ethereal emotions in imaginative occupations, day-dreams and night sighs, which perhaps would not much have disturbed William if he had known of them" (Hardy 1990, 380).

5 From the beginning, the ironic tone is set. Despite her absolute dependence on her husband, Ella comes to foster impassioned feelings for a poet called Trewe whose writings she admires without knowing or ever meeting him. As a lover of poetry and amateur poet herself, she is extremely moved when she discovers that the rooms her husband has decided to rent during the family's holiday on the seaside are the lodgings of a young poet who resides there during the rest of the year.

6 Unseen by anyone, she scrutinizes the photograph which she finds on the mantelpiece, concealed behind a portrait of Royalties: "What possessed her she could not have described" (388), the narrative voice observes, but she guiltily hides the photo under her pillow when Mr Marchmill enters the bedroom without notice. Unrevealed, she catches every possible glimpse of the "pencillings on the wall-paper beside her head", which are lines the poet inscribed some time ago in his bedroom, above the bed where she sleeps with her husband: "There they were - phrases, couplets, bouts-rimés, beginnings and middles of lines, ideas in the rough, like Shelley's scraps, and the least of them so intense, so sweet, so palpitating, that it seemed as if his very breath, warm and loving, fanned her cheeks from those walls, walls that had surrounded his head times and times as they surrounded her own now" (389-390). Ella is seduced by those words which have a sensual quality attached to them. The lines and forms she looks at touch her as delicately as the hands of the poet might have done. The writer is both present through them and wholly absent, his ghostly presence eroticising the words on the bedroom walls. The letters define the contour of his spectral body which can be imagined and even felt, though never seen.

7 The erotic quality of the reading experience explains why the young lady longs to be alone and unseen in order to indulge her passion: "Ella Marchmill flushed without knowing why, and suddenly wished her companion would go away [...]. An indescribable consciousness of personal interest rather than literary made her anxious to read the inscription alone; and she accordingly waited till she could do so, with a sense that a great store of emotion would be enjoyed in the act" (385).

8 In a similar fashion, before looking at the photograph of the poet, she takes care of details in a setting where her emotions are to be roused, as if getting ready for her wedding night:

To gratify her passionate curiosity she now made her preparations, first getting rid of superfluous garments and putting on her dressing-gown, then arranging a chair in front of the table and reading several pages of Trewe's tenderest utterances. [...] As she gazed long at the portrait she fell into thought, till her eyes filled with tears, and she touched the cardboard with her lips. Then she laughed with nervous lightness, and wiped her eyes. (389)

9 The text depicts Ella's ever-increasing attraction to the poet until she plainly falls in love with him (387). Although he is "a man she had never seen" (385), the notion of platonic love is excluded. The human, bodily attraction is always underlined and the letter does not put it at a distance but rather enhances it. In the preface quoted above, Hardy evoked "the physical possibility that may attach to a wife of vivid imaginings". This reference to 
the body and to "medical practitioners" recalls the disturbing question of hysterical women whose condition gained interest and notoriety in the late nineteenth century.

At times indeed, "the poetic impulse having waxed strong again, Ella was possessed by an inner flame which left her hardly conscious of what was proceeding around her" (385). Her partial loss of consciousness mentioned by the narrator is characteristic of hysteria whose study by Freud gave birth to psychoanalysis. Taken under Freudian scrutiny, the hysterical discourse appeared to give voice to the unconscious, which is the basis of the "talking cure" and constitutes a defence against the discourse of the master. Although in the short story Ella's experiences are mostly silent and discreet, she is repeatedly witnessed flushing, acting or speaking in a way she does not control: "What possessed her she could not have described" (390), but she talks "with a tremor in her gentle voice which she herself felt to be absurdly uncalled for" (391). "Possessed of her fantasy" (386) she tries on the poet's clothes she has found in a closet and has to lie to her husband to justify her behaviour. As Lacan suggests, "[t]he unconscious is rooted in the fact that the hysterical woman does not know what she says, and yet she does say something through the words that she lacks. The unconscious is a sediment of language" (Lacan 1981, 1, my translation).

11 The "inner flame" felt by Ella is fuelled by the erotic quality of the poems written by Trewe. As one of his friends tells her, "[h]is poetry is rather too erotic and passionate, you know, for some tastes" (Hardy 1990, 395). The young lady succumbs to the sensuality of the words that seem to caress her soul and body alike. They are a prolongation of the writer's body: by their metonymic function they sustain Ella's desire ${ }^{2}$. They also characterise Lacan's definition of hysteria which combines an enigmatic use of language with sexual undertones:

[...] words have body, which does not mean at all that we understand anything about them. That's the unconscious; we are led by words we do not understand. [...] Sexuality is caught in those words [...]. This fact matters more than to know what the unconscious means or does not mean. Freud insisted on this aspect. That's what hysteria itself boils down to. ${ }^{3}$ (Lacan 1999, 3)

The power of words takes pride of place and occults what truly happens. Ella comes very, very close to committing adultery. She does so by proxy, through the act of reading which replaces the sexual intercourse. Her husband even ends up believing that their last child is the offspring of his wife's infidelity. Ella's imaginings literally build up a new reality, and in that respect she is hysterical. What is in her mind comes to shape her world. She eventually overacts, leaving on a trip to visit the poet's grave (Hardy 1990, 398-399) without telling her husband who finds her weeping in the dark in a cemetery, miles away from their home. Her excessive feelings - "her eccentricities" (398) - kill her. She is another example of Bovarysme which has often been related to hysteria; so was it first with Baudelaire who underlined this aspect of Flaubert's heroine in his article on Madame Bovary, a novel published in $1857^{4}$.

Like Emma, Ella is dissatisfied with her life and her husband. She attempts to escape through imagination and love, but fails. While the latter reads novels, the former chooses poems. A similar pattern is repeated in another short story in the Life's Little Ironies collection, which is entitled "On the Western Circuit" and whose main action is letterwriting. The protagonist is Edith Harnham, a refined lady who decides to take care of her maid, Anna. The latter is seduced by a young lawyer, Charles Bradford Raye, on a tour in the south-west of England, and she becomes pregnant. Raye living in London, Mrs 
Harnham advises her protégée to write and get him to marry her. Anna being illiterate, the lady will do the writing, without letting the addressee know about it. Thanks to Mrs Harnham's skill as a letter-writer, Raye asks Anna to marry him. In the final scene, the young bride's happiness only serves to put into relief Raye's and Mrs Harnham's grief: indeed they have been mutually conquered by the other's words. Raye's true desire is for Edith Harnham and it is her he ought to have married. As to Mrs Harnham, she has to leave the young couple alone and go back home to her husband.

As in "An Imaginative Woman", the letter is at the core of the narrative. The action lies in the handwriting itself. The signifier "hand", therefore, is recurrent in the text. Significantly, the first meeting between Raye and Edith Harnham in the middle of a crowd sets the movement off: "Mrs Harnham then felt a man's hand clasping her fingers, and from the look of consciousness on the young fellow's face she knew the hand to be his: she also knew that from the position of the girl he had no other thought than that the imprisoned hand was Anna's. What prompted her to refrain from undeceiving him she could hardly tell. Not content with holding the hand, he playfully slipped two of his fingers inside her glove, against her palm. Thus matters continued till the pressure lessened; but several minutes passed before the crowd thinned sufficiently to allow Mrs Harnham to withdraw" (460).

The exchange of letters will prolong the sexual game initiated here. In writing them, Mrs Harnham will continue to pretend that she is Anna, thus dramatizing her femininity in a way that evokes the female masquerade ${ }^{5}$. She makes believe she is that young girl she wanted to protect but of whom she tells Raye just before he caresses her hand: "In that case, I'll leave her in your hands" (460). Raye deems Anna "an artless creature whose inexperience had, from the first, led her to place herself unreservedly in his hands" (463). Mrs Harnham, being far more experienced, will take advantage of the maid's naivety and run the show with her skilful hand $(464,466)$.

Edith meets the one she falls in love with. She knows the touch of his hand and even the taste of his lips, whereas Ella can only contemplate the poet's portrait and kiss the lock of hair that is sent to her on her request after his death. Yet, the intercourse between Raye and Mrs Harnham is brief and unsatisfactory as it is based on double-dealing and misunderstanding. The latter's urgent need to observe the object of her newly aroused desire after the first meeting in the crowd, repeats Ella's contemplation of the photograph: "She was so gently stirred by the stranger's manner and voice, with the tenderness of his idle touch, that instead of re-entering the house she turned back again and observed the pair from a screened nook (460-461). Then, as she can no longer watch, hear or talk to the beloved one, she will read him.

The correspondence - like the reading of the poems for Ella - will answer and fuel her longing, as it finds an echo in her dissatisfaction with her marriage: "That contract had left her still a woman whose deeper nature had never been stirred" (467). Although Edith and Raye have an opportunity to meet one last time on the day of his wedding to Anna, and avow their feelings to each other, communication remains rooted in falsehood and misunderstandings. The young man is "chained to work for the remainder of his life, with her, the unlettered peasant, chained to his side" (476). Edith is tied in holy matrimony to "a man" (459) without a name, "the worthy merchant" (476) who vaguely appears twice and each time in the dark. 

and will remain "unrevealed, unmet, unknown" (396). Trewe illustrates the Lacanian viewpoint that the woman is not all - pas toute ${ }^{6}(\operatorname{Lacan} 1975,13)$ - and always missing for the man as a real subject; she only appears as an object of desire, as "fantasy" (Lacan $1975,58)$. He dreams of "the imaginary woman alone" while Ella is "an imaginative woman": here is another of life's little ironies. Ella herself is in love with a poet but she only knows his words. The total inadequacy of the exchanges and desires brings to mind Hardy's conception of man as an emotional creature: "A woeful fact - that the human race is too extremely developed for its corporeal conditions, the nerves being evolved to an activity abnormal in such an environment" (Florence Emily Hardy 118). Hysteria, blurred identities and hopes are the inevitable consequences of the abnormality of the human condition. Her pseudonym is John Ivy and rhymes with the "sad and hopeless envy" with which she had "often and often scanned the rival poet's work, so much stronger as it always was than her own feeble lines" (Hardy 1990, 383). Like the plant of the same name, she tries to shape her own art along the lines of her model's but can never equal it: "She had imitated him, and her inability to touch his level would send her into fits of despondency" (383).

The choice of the name therefore underlines the ambiguity of her desire for Trewe, whose own patronymic ironically suggests truthfulness and authenticity. Ella loves the objects the poet produces rather than the man himself because they are all she ever gets from him. What develops between them is a mock intercourse taking place through the few letters they exchange. The truth being never revealed, the interpretation of facts is what counts: for Trewe there is nothing more than an exchange of letters with a fellow poet called John Ivy, whereas, in the husband's eyes, the link between Trewe and Ella amounts to adultery. The correspondence and the dialogues do not allow for communication to function. All that is let out is a dialogue of the deaf.

Ella does not see the other as an alter ego, but always as an object ${ }^{8}$. She might stand for the elegant, respectable Victorian woman, the devoted mother and dutiful wife, being aware that her comfort and social status entirely derive from her husband. However she sees her marriage with the gun-maker as a strange reality, both necessary and alien to her: "She had never antecedently regarded this occupation of his as any objection to having him as a husband. Indeed, the necessity of getting life-leased at all cost, a cardinal virtue which all good mothers teach, kept her from thinking of it at all till she had closed with William, had passed the honeymoon, and reached the reflecting stage. Then, like a person who has stumbled upon some object in the dark, she wondered what she had got; mentally walked round it, estimated it; whether it were rare or common; contained gold, silver or lead; were a clog or a pedestal, everything to her or nothing" (380). The word "have" being first used about "him", the expression "what she had got" could refer either to her marriage as a whole, or to Marchmill himself. In the process, her husband is denied the status of a subject.

The general impression is that she is gradually getting in control in a more and more audacious way. She hides to read, then she sleeps with the poet's photograph under her pillow; she starts a correspondence with him under a false name, invites him at her home and eventually flees from her family to go and weep over his grave. Ella's masculinity shows through a few hints like her pretending to be John Ivy or her masquerading in Trewe's garments. 
wrote that there was a definite masculine side to $\mathrm{her}^{10}$. For all his creative art, Flaubert could not but infuse masculinity into his female character. To him, woman remains an ungraspable mystery. This might also be said of Hardy who, although he married twice, voiced his disillusion with marriage in his works as well as in letters or essays. In a short contribution to a symposium on the theme of marriage he wrote: "As your problems are given on the old lines so I take them, without entering into the general question whether marriage, as we at present understand it, is such a desirable goal for women as it is assumed to be; or whether civilisation can escape the humiliating indictment that, while it has been able to cover itself with glory in the arts, in literatures, in religions, and in the sciences, it has never succeeded in creating that homely thing, a satisfactory scheme for the conjunction of the sexes" (Hardy 1966, 119).

The disillusion is echoed by the regret Hardy conveys in his poems of 1912 written after Emma, his first wife, died. Obsessed with this inadequacy of the sexes, which finds its modern expression in Lacan's "Il n'y a pas de rapport sexuel, mais des relations, il n'y a que cela"11 (Lacan 1975, 17), he treats the questions repeatedly in his novels, the most powerful of which are tragic. His attempt at grasping woman in essence gave birth to his 
most famous literary creation, in which he shuffles off his manly coil and gives voice to femininity: Tess. It is she who, in the poem entitled "Tess's Lament", perhaps expresses best the author's deep feeling of unspeakable regret and universal tragedy: "I'd have my life unbe" (Hardy 2001, 161). A lament that is reminiscent of Antigone's "O that I was never born!"

The two short stories do not share the sad pastoral tonality of Tess of the D'Urbervilles. Nonetheless, the use of the coined word "unbe" in "Tess's Lament" directs our attention to Hardy's attachment to the letter. The true centre - or perhaps master - in the tales is the letter itself. Because of it, Trewe is deceived by Ella alias John Ivy, and so is Raye by Edith Harnham alias Anna. But those seemingly phallic women are ultimately confronted with their own failure and frailty, because they are subjected to the power of the letter and come to reflect what the letter dictates. In "On the Western Circuit", both writers fall in love with an other who exists only through the letters they read. So that when the correspondence is over, Edith has to recognize that she is not what she has pretended to be: "Throughout this correspondence, carried on in the girl's absence, the high-strung Edith Harnham lived in the ecstasy of fancy; the vicarious intimacy engendered such a flow of passionateness as was never exceeded" (Hardy 1990, 470).

In the act of writing, she forgets about the fancy, taken in as she is by the authority of the letter. She evades her true identity to become another self shaped by words. But this spectral being is ephemeral: for spoken words, and not written words, remain ${ }^{12}$ (Lacan 1999, 27). What is left is the impossible love between Edith and Raye as their ultimate conversation stresses, as well as the indissoluble, carnal bond between Anna and the young man.

30 As for Ella, she cannot meet the poet through his words because he is not in them - or not only in them. She cannot pretend to be John Ivy any longer, and she will never be "the imaginary woman" (Hardy 1990, 396) of Trewe's dream. Conversely, her husband adds his own words and writes his own story, filling the gaps that show between the fragments of a passion that his wife leaves behind when she dies. Her craze for the poet's words brings her to her death; she is "acting by the letter; and 'the letter killeth"' (Hardy 1999, 465) as Jude the Obscure well knows.

31 For in the letter, there is something that escapes both the writer and the reader. There is always a remainder - un reste. The irony of Hardy's writing derives from this surplus this litter of the letter that exceeds the characters' meaning. The irony becomes tragic as the protagonists are confronted with the unavoidable absence of an answer to a desire that can live and endure only through the words on the page. This is movingly evoked in the farewell letter Trewe leaves behind before committing suicide: "I have long dreamt of such an unattainable creature, as you know; and she, this undiscoverable, elusive one, inspired my last volume" - a volume entitled "Lyrics to an Unknown Woman" (Hardy 1990, 396).

Once the power of the letter seems to be put at a distance after Trewe's death or after the end of the correspondence between Edith and Raye, the "fantasy" (397) vanishes and, just as in Jude the Obscure, the false hopes "burst up, like an iridescent soap-bubble" (Hardy $1999,138)$. The characters are left with a feeling of regret and despair, only too well aware of the impossibility of their desire: "O, if he had only known of me - known of me - me! ... O, if I had only once met him - only once; and put my hand upon his hot forehead kissed him - let him know how I loved him - that I would have suffered shame and 
scorn, would have lived and died, for him! Perhaps it would have saved his dear life! ..." (Hardy 1990, 397). The other's body is captured in a dream which becomes a dead letter; the kiss on the forehead is virtual and serves to remind the young lady of the absence of the beloved one. But at the same time her words suggest she has unknowingly achieved her dream: her voice is that of a poet now.

Edith's regret at being inevitably cut off from the writer who addresses Anna is also felt and expressed through the body. After their first encounter, "[s]he wished she had married a London man who knew the subtleties of love-making as they were evidently known to him who had mistakenly caressed her hand" (462). Later on, she feels how unbearable her situation is when she longs for what Anna has: "I wish his child was mine - I wish it was' she murmured. 'Yet how can I say such a wicked thing!'” (469).

In this sentence we can feel how close Hardy comes to the enigmatic question of Woman's jouissance while reinstating the Law with its interdictions and codes. The Letter appears in its duality: as the Letter of the Law, it kills and petrifies, confining people to definite categories in terms of marriage, name, or sex. As the poetic letter, it can evoke love, desire, or create a brand new world through a language that tells simultaneously a lot more and a lot less than the Real it tries to grasp.

The erotic undertones we mentioned earlier in "An Imaginative Woman", the recurring allusions to the body, love and longing, as well as the hints to hysteria suggest how subversive the two protagonists' desire is. Edith knows her wish is "wicked" while Ella feels that "it was not allowed! God is a jealous God; and that happiness was not for him and me!" (397).

In Hardy's universe, the Law is never invalidated so that it invariably imposes its rule. And it does so through the letter which becomes immovable when it consists in duplicating what has already been inscribed through the bodies: the wedding between Anna and Raye is "the ratification of a previous union" (473) and nothing else can be tied together. Trewe's quest for the ideal woman - like the knight's quest for the unreachable lady of courteous love - belongs to a world outside the Law, so that it is doomed to fail. It might be the poetic version of Hardy's own pursuit of the "Woman much missed" (Hardy 2001,346 ). While the young poet opts for death as the only way to stifle his unbridled craving, Hardy continued his writing. Through his novels and his poems, the women he shapes are facets of the "imaginary woman alone", whose names are Tess, Sue, Bathsheba, Elizabeth-Jane... As Lacan puts it, the woman doesn't exist ${ }^{13}$ (Lacan 1975, 68). She has to be invented in full - en toutes lettres.

\section{BIBLIOGRAPHY}

Lacan, Jacques, Le Séminaire, Livre XX, Encore, 1972-73, ed. Jacques-Alain Miller, Paris: Seuil, 1975.

Lacan, Jacques, “Intervention de Jacques Lacan à Bruxelles" ("Propos sur l'hystérie"), Quarto n², Revue de la Cause Freudienne, Bruxelles, 1981.

Lacan, Jacques, Ecrits I, Paris: Seuil (1966), 1999.

FATHOM, 1 | 2013 
Hardy, Florence Emily, The Life of Thomas Hardy, 1840-1928, London: Macmillan, 1962.

Hardy, Thomas, Life and Art, New York: Haskell House, 1966.

Hardy, Thomas, Thomas Hardy's Personal Writings, ed. Harold Orel, London: Macmillan, 1967.

Hardy, Thomas, Collected Short Stories, London: Papermac, Macmillan, 1990.

Hardy, Thomas, Jude the Obscure (1895), New York: Norton (1978), 1999.

Hardy, Thomas, The Complete Poems, Basingstoke and New York: Palgrave, 2001.

\section{NOTES}

1. "L'inconscient s'origine du fait que l'hystérique ne sait pas ce qu'elle dit, quand elle dit bel et bien quelque chose par les mots qui lui manquent. L'inconscient est un sédiment de langage".

2. "[D]esire is a metonymy" ("[L]e désir est une métonymie", Lacan 1999, 526, my translation).

3. “[L]es mots font corps, ça ne veut pas dire du tout qu'on y comprenne quoi que ce soit. C'est ça l'inconscient, on est guidé par des mots auxquels on ne comprend rien. [...] La sexualité est entièrement prise dans ces mots [...]. C'est bien plus important que de savoir ce que veut dire ou ne pas dire l'inconscient. Freud a mis l'accent sur ce fait. Tout cela, c'est l'hystérie elle-même".

4. Hardy knew about French literature, as his alluding to Zola and Dumas père shows in his essay entitled The Science of Fiction (Hardy 1966, 86).

5. The notion was introduced by Joan Rivière in an article entitled "Womanliness as a masquerade", International Journal of Psychoanalysis, 10, 303-313 ("La féminité en tant que mascarade”, trad. fr. dans Féminité mascarade, Paris, Le Seuil, 1994, p. 197-213).

6. "[I]l n'y a pas la femme, la femme n'est pas toute".

7. "C'est pour autant que l'objet a joue quelque part - et d'un départ, d'un seul, du mâle - le rôle de ce qui vient à la place du partenaire manquant, que se constitue ce que nous avons l'usage de voir surgir aussi à la place du réel, à savoir le fantasme".

8. "Ella" means "she's got" in French.

9. "[T] out semble concerté pour que le personnage que tous ses propos ont cerné des traits de la virilité, dégage quand il apparaît l'odor di femina la plus singulière". (Lacan 1999, "Le séminaire sur 'La Lettre volée”', 35)

10. "Il ne restait plus à l'auteur, pour accomplir le tour de force dans son entier, que de se dépouiller (autant que possible) de son sexe et de se faire femme. Il en est résulté une merveille ; c'est que, malgré tout son zèle de comédien, il n'a pas pu ne pas infuser un sang viril dans les veines de sa créature, et que madame Bovary, pour ce qu'il y a en elle de plus énergique et de plus ambitieux, et aussi de plus rêveur, madame Bovary est restée un homme". (Charles Baudelaire, Madame Bovary par Gustave Flaubert, in L'Artiste, 18 octobre 1857).

11. The expression is traditionally translated as follows: "There is no such thing as a sexual relationship, but relationships are all what there is" (my translation), the meaning being that there is no relation, no reciprocity between the male and female sexual positions.

12. "Plût au ciel que les écrits restassent, comme c'est plutôt le cas des paroles [...]". Les écrits emportent au vent les traites en blanc d'une cavalerie folle. Et, s'ils n'étaient feuilles volantes, il n'y aurait pas de lettres volées".

13. "La femme, ça ne peut s'écrire qu'à barrer $L a$. Il n'y a pas $L a$ femme”. 


\section{ABSTRACTS}

The article deals with two short stories by Thomas Hardy: "An Imaginative Woman" and "On the Western Circuit". The first text introduces Ella, the disillusioned day-dreaming wife of a gunmaker. As a lover of poetry and amateur versifier herself, she is extremely moved on learning that the rooms her husband has rent for the family's holiday are the lodgings of a young poet who resides there during the rest of the year. As she discovers verses inscribed by the poet himself on the wall just above her bed, her stirring reading experience takes on an undeniably erotic quality, bringing about the disturbing question of hysteria which gained interest and notoriety in the late nineteenth century.

In the other short story, entitled "On the Western Circuit", the exchange of letters becomes a means to woo and seduce. In both stories, the main woman's masculinity is gradually underlined, while the man engaged in the exchange - the young poet in "An Imaginative Woman", a young lawyer in the other text - is feminized. Nevertheless, the seemingly phallic women are ultimately confronted with their own failure and frailty, because they are subjected to the power of the letter and come to reflect what the letter dictates. They have to renounce the object of their love and desire. But in the process, it appears that their feminine voices have acquired a poetic dimension, being able to suggest and unveil much more than what the succession of letters on the page seemed to signify.

Cet article porte sur deux nouvelles de Thomas Hardy: «An Imaginative Woman » et "On the Western Circuit ». La première dépeint Ella, l'épouse rêveuse et mélancolique d'un fabriquant d'armes. Passionnée de poésie, elle est fortement émue lorsqu'elle apprend que la maison où son mari a décidé que la famille ferait un séjour estival est aussi le lieu de résidence d'un jeune poète durant le reste de l'année. Dans une chambre elle découvre des vers que le poète a lui même écrits sur le mur au-dessus du lit: la lecture de ces bribes d'écriture revêt une connotation érotique qui laisse affleurer la question de l'hystérie, dont les manifestations surprenantes et dérangeantes devinrent peu à peu sujet d'étude à la fin du dix-neuvième siècle.

Dans la seconde nouvelle intitulée "On the Western Circuit», l'échange de lettres se fait instrument de séduction. Dans les deux textes, la femme est le personnage principal et sa masculinité est soulignée. Au contraire, l'homme de l'histoire - le jeune poète dans «An Imaginative Woman", un jeune avocat dans l'autre récit - est féminisé au travers de la correspondance. Cependant, la femme qu'on aurait pu dire phallique va être confrontée à sa propre fragilité et à la perte parce que, soumise au pouvoir de la lettre, elle en vient à être le reflet de ce que dicte cette lettre. Elle doit renoncer à l'objet de son amour et de son désir. Mais dans cet acte d'abandon elle trouve sa voix, une voix féminine qui acquiert une dimension poétique et parvient à dévoiler bien plus que ce que la succession de lettres sur la page ne laisse entrevoir. 
INDEX

Mots-clés: nouvelle, féminité, lettre, genre, amour, désir, psychanalyse, Lacan (Jacques), ironie Keywords: short story, femininity, letter, gender, love, desire, psychoanalysis, Lacan (Jacques), irony

oeuvrecitee Imaginative Woman (An), On the Western Circuit

\section{AUTHOR}

\section{STÉPHANIE BERNARD}

Université de Rouen

Maître de conférences 